\title{
Interpretation of Judicial Review of The Law Number 42 of 1999 On Fiduciary Guarantee Regarding the Decision of Constitutional Court Number 18/PUU-XVII/2019
}

\author{
Tasrif $^{\mathrm{q}}$ \\ \{tasrif_bima@yahoo.co.id \& tasrif@wom.co.id \} \\ ${ }^{1}$ Student of Law Doctoral Program, Universitas Jayabaya Jakarta, Indonesia
}

\begin{abstract}
The issuance of Decision of the Constitutional Court Number 18/PUUXVII/2019 on Petition for Execution of the District Court triggers a conflict of interest, especially the interests of fiduciary recipients (creditors). The research questions in this study are First, how is the interpretation of the Judges of Constitutional Court in conducting a judicial review of Article 15 paragraph (2) of the Fiduciary Guarantee Law. Second, what is the view of legal experts and the public regarding the results of the judicial review of Article 15 paragraph (2) of the Fiduciary Guarantee Law. The results of this research show that the results of the judicial review issued in the decision of Constitutional Court Number 18/PUUXVII/2019 apparently did not provide legal protection and legal certainty for fiduciary recipients in terms of carrying out the execution of fiduciary security objects.
\end{abstract}

Keywords: Juridical Interpretation, Judicial Review, Constitutional Court

\section{Introduction}

The issuance of Decision of the Constitutional Court Number 18/PUU-XVII/2019 concerning Application for Execution to the District Court, on January 6, 2020 is as a result of the material test of Article 15 paragraph (2) along with its explanation and Article 15 paragraph (3) of Law Number 42 of 1999 concerning Fiduciary Guarantees. In line with the title of this paper, the author will discuss and review the legal interpretation of the Constitutional Court judges in conducting the material review of Article 15 paragraph (2) of the Fiduciary Guarantee Law, and discuss and examine the perceptions of some legal practitioners in assessing the results of the judicial review of material allegedly more impartial in the interests of the fiduciary giver, and overrides aspects of legal protection and legal certainty for fiduciary recipients (creditors).

On the other hand, the review of the Constitutional Court's ruling shows that the Constitutional Court is too hasty in making a decision that has a big impact on the public and finance companies. In the ruling, the Court only saw one case out of thousands of cases or even millions of cases of "credit defaults" that were happening in the community. Supposedly, the Constitutional Court is more concerned with bad credit and cases of unscrupulous mafia leasing which are detrimental to creditors who may reach trillions of rupiah, with various modes of operation. Cases like the one above. should be a consideration for the Constitutional Court before deciding because the objects which are the object of collateral are movable objects and it is not certain that the vehicle is always in the same place.

Therefore, in the writing of this journal, the problem is limited first, how is the interpretation of the Constitutional Court Judges in conducting a material test of Article 15 paragraph (2) of the Fiduciary Guarantee Law. Secondly, what is the view of legal experts and the public regarding the results of the judicial review of Article 15 paragraph (2) of the Fiduciary Security Act, and their explanation 


\section{Method}

This research used normative juridical research method by examining inter-related legislation. For example, this research examined the Constitutional Court judge's legal interpretation in conducting a judicial review of the Fiduciary Guarantee Law, the decision of which has permanent legal force (incracht) as regulated in Article 1 paragraph (1) of Law Number 48 of 2009 on Judicial Power, stating that the judge's decision is an independent to administer justice in order to enforce law and justice.

\section{Results and Discussion}

The results showed that there had been an unlawful act with case registration Number 345/PDT.G/2018/PN.Jkt.Sel. This case is a case of breach of four-wheeled motor vehicles resulting in the forced withdrawal of fiduciary collateral objects (in the form of a Toyota Alphard V Model 2.4 A / T 2004) by the creditor. In this case, the South Jakarta District Court granted the petition of the two petitioners, the Court was of the opinion that the norms of Article 15 paragraph (2) and (3) of the Fiduciary Guarantee Law had no legal certainty regarding the procedure of execution or the time when the fiduciary giver (debtor) declared "breach of promise" (default) and loss of opportunity for the debtor to get the sale of fiduciary collateral objects at a reasonable price.

This section discusses the issues stated in the problem formulation, including:

\subsection{Interpretation of the Constitutional Court Judges regarding the Judicial Review of the Fiduciary Guarantee Law}

The provisions of Article 15 paragraph (2) and paragraph (3) of the Fiduciary Security Act (the a quo Law), in principle, provide guarantees and legal certainty protection for fiduciary recipients (lenders) in providing credit to fiduciary givers (debtors). This protection of legal certainty is clearly seen in the weighing considerations which are the basis for the establishment of the Fiduciary Security Act. The form of guarantee and protection of legal certainty in granting such credit, is shown by the arrangement of guarantee of execution of fiduciary objects, by equating the executorial power of the Fiduciary Guarantee Certificate with a court decision that has permanent legal force [vide Article 15 paragraph (2) of the Fiduciary Guarantee Act]. Therefore, the Fiduciary Guarantee Certificate includes the words "FOR JUSTICE UNDER THE ALMIGHTY GOD" like a court decision [vide Article 15 paragraph (1) of the Fiduciary Guarantee Law]

Based on the provisions of Article 15 paragraph (2) of the aforementioned a quo law, the main principle of this fiduciary institution is to provide legal certainty to immediately execute fiduciary objects, because it has strengthened the right to fiduciary recipients (creditors) to sell objects that become the object of fiduciary security over his own authority, in the case of a defaulting debtor. The provisions in article a quo only focus on providing legal certainty over the rights of fiduciary recipients (creditors) by directly executing fiduciary objects. For this reason, this provision finds weaknesses, especially in providing meaningful details of its implementation which can actually violate the rights of fiduciary providers (debtors). The provisions of the article a quo actually escaped to provide fair legal certainty, guarantees, and equal treatment before the law, as well as protection of the private property of the fiduciary giver (debtor).

The incomplete contents of Article 15 paragraph (2) of the Fiduciary Guarantee Law has implications for ignoring the principle of legal certainty and legal justice, because it is more likely to protect fiduciary recipients rather than protecting the interests of consumers (fiduciary givers). Supposedly by equating "fiduciary certificates" with "court decisions that have permanent legal force", the procedure for executing fiduciary objects should also be equaled or at least similar to the procedure for executing court decisions that have permanent legal force (incracht van gewijde) 


\subsection{Interpretation of the Parties to the results of judicial review of the Fiduciary Guarantee Law}

The Constitutional Court stated clearly and clearly that the constitutionality aspect contained in the norms of Article 15 paragraph (2) of the Fiduciary Guarantee Act did not reflect the provision of balanced legal protection between the parties bound in the fiduciary agreement and also the object which became the Fiduciary Guarantee, both legal protection in the form of legal certainty and justice. Because, the two fundamental elements contained in the article a quo, namely "executorial title" or "likened to a court decision that has permanent legal force", implies that execution can be carried out immediately as if it were the same as a court decision that has permanent legal force by the fiduciary recipient (creditor) without the need to ask for court assistance for the execution.

In this paper the author includes several views of experts, the purpose of which is to have a balance of justice to debtors and creditors. Some of these views or interpretations, including:

1) Government View

The Government or President also provides a written statement. According to the government, what the Petitioner argues is not a constitutional loss that is contrary to the Constitution. The Petitioner should understand well that the Fiduciary Guarantee Law as the basis for the Petitioner's engagement, especially the provisions on the execution of fiduciary guarantees. The Government is of the opinion that the Fiduciary Guarantee Certificate Number WII.0167952. AH.05.01 is evidence that the Petitioner has entered into a civil agreement as a fiduciary agreement. Normatively, this agreement acts as a law for those who make it. Like it or not, the applicant must obey and abide by the contract that was made.

In accordance with the evidence of the Fiduciary Certificate, the Petitioner's loss is a legal loss on a civil basis. Even if the petitioner questions, it is more about the implementation of the agreement, namely the execution of fiduciary guarantees. This is also evident from the South Jakarta District Court Decision Number 345 / PDT.G / 2018 / PN.Jkt. Cell who granted the plaintiff's claim to partially prove that a legal dispute from a civil dispute became a criminal dispute. The government is of the view that "the arguments of the Petitioners' losses have clearly been the arguments of legal damages in a civilian manner with objects that can be counted in real terms, whose implementation is based on fiduciary guarantee engagement laws.

\subsection{The views from the government experts}

Government experts consisting of 2 (two) lecturers at the Faculty of Law, University of Indonesia, and lecturers at the Jentera Law College, explained that after the enactment of the Fiduciary Security Law, the execution was regulated in Chapter V starting from Article 29 to Article 34. One the form of execution as regulated in Article 29 is the implementation of the executorial title referred to in Article 15 paragraph (2) of the Fiduciary Security Act. Therefore, the provisions of Article 15 paragraph (2) cannot be separated from the provisions of Article 29 of the Fiduciary Security Act.

One of the special guarantee characteristics of material is that it is easy to execute. This is based on the consideration that in a special material security guarantee, the debtor has bound himself with the creditor to provide specific guarantees to the creditor in the form of certain objects owned by the debtor to guarantee the debtor's obligations as stated in the main agreement if the debtor defaults. In addition to the object that has been specifically designated, the special guarantee of material also indicates a special relationship between the creditor and the debtor based on the agreement. With this specificity, the execution mechanism also needs to be regulated specifically (lex specialis) which is different from the execution in general.

\subsection{The views from the House of Representatives}

In its statement, the House of Representatives emphasized that the Petitioner did not describe concretely the related rights and/or constitutional authorities as what was impaired by the 
provisions of article a quo. The Petitioners only described the problems experienced by the Petitioners' own default.

In the view of the House of Representatives, the Fiduciary Guarantee Law instead provides legal guarantees both for fiduciary givers and fiduciary recipients. Provisions in the Law a quo has clearly stipulated how the execution of the fiduciary guarantee object can be carried out and what are the obligations and rights of the parties. Therefore, there are no constitutional rights and/or authorities of the Petitioners who are disadvantaged by the coming into effect of Article 15 paragraph (2) and paragraph (3) of the Fiduciary Guarantee Law. In addition, there are no constitutional rights and/or authorities of the Petitioners who are disadvantaged by the enactment of the provisions of Article 15 paragraph (2) and paragraph (3) of the Fiduciary Guarantee Law. Because there are no constitutional rights and/or authorities of the Petitioners who are harmed. Therefore, there is no specific and actual or potential loss that can be ascertained.

The House of Representatives also believes that the Petitioners as a whole do not have a legal position (legal standing) because it does not meet the provisions of Article 51 paragraph (1) and the Elucidation of the Law on the Constitutional Court, and does not meet the requirements of the constitutional impairment which was decided in the decision of the previous Constitutional Court. Moreover, the Petitioners did not concretely describe their constitutional rights and/or authorities which were considered to be impaired due to the enactment of the provisions of the Fiduciary Guarantee Law.

\section{Conclusion}

The provisions of Article 15 paragraph (2) and paragraph (3) of the Fiduciary Guarantee Law (A quo Law), in principle, provides guarantees and legal certainty protection for fiduciary recipients (creditors) in providing credit to fiduciary givers (debtors). However, in the case of debtor's default, the Constitutional Court decision Number 18/PUU-XVII/2019 stated that the execution of the fiduciary guarantee object execution must go through court procedures as regulated in Article 196 HIR or Article $208 \mathrm{RBg}$., except if the debtor recognizes the default it does. However, the problem is that the execution through court procedures certainly takes a long time and needs a lot of costs. This is where aspects of legal protection and legal certainty for creditors are ignored.

To avoid a prolonged conflict of interest regarding the absence of legal certainty and legal protection for creditors for the issuance of the Constitutional Court Decision Number 18/PUUXVII/2019, it is better that the Fiduciary Guarantee Law (a quo status) needs a comprehensive review at least the revision of Article 15 paragraphs (2) and (3). Therefore, the results of the judicial review of the Fiduciary Guarantee Law can provide legal protection and legal certainty for both creditors, debtors, and KPKNL.

\section{Acknowledgments}

The author would like to thank profusely to all those who have helped and supported the completion of the writing of this journal, especially the authors thank the Chairman of the Doctoral Program / Postgraduate Director and thank the authors to the UNNES for providing facilities to join in the International Conference in ICESI 2020 UNNES.

\section{References}

[1] The Law Number 42 of 1999 on Fiduciary Guarantee.

[2] https://indonesia.go.id/layanan/kependudukan/ekonomi/judicial-review-ke-mahkamahkonstitusi.

[3] https://www.hukumonline.com/berita/baca/lt5e13345852149/mk-tafsirkan-cidera-janjidalam-eksekusi-jaminan-fidusia/

[4] https://mkri.id/public/content/persidangan/putusan/putusan_mkri_6694.pdf.

[5] https://www.hukumonline.com/berita/baca/lt5e314a1af314d/peta-pandangan-para-pihaksebelum-putusan-mk-tentang-jaminan-fidusia/. 